\title{
Thermal treatment of waste from the meat industry in high scale rotary kiln
}

\author{
P. Staron ${ }^{1} \cdot$ Z. Kowalski ${ }^{1}$ A. Staron ${ }^{1} \cdot$ M. Banach ${ }^{1}$
}

Received: 16 June 2016/Revised: 4 November 2016/Accepted: 21 December 2016/Published online: 9 January 2017

(C) The Author(s) 2017. This article is published with open access at Springerlink.com

\begin{abstract}
Recently there has been an increase in consumption of meat, especially poultry. This results in an increase in the quantity of waste, including waste feathers. Waste from the meat industry are hazardous, which must be disposed of in accordance with the law. Wastes from the meat industry normally consist of valuable elements such as phosphorus, calcium, potassium, magnesium (macronutrients), and iron, copper, zinc, manganese (micronutrients), which after suitable processing can be used for the purposes of fertilization. The paper presents the results of thermal treatment of feathers with meat and bone meal and feathers with poultry litter in a high scale rotary kiln. Mixtures of wastes were incinerated in temperature range from 600 to $900{ }^{\circ} \mathrm{C}$ for about $20-25 \mathrm{~min}$. The resulting ashes were characterized by a high content of phosphorus (4-17\%), calcium (17-30\%) and potassium $(0.6-3.6 \%)$. The study revealed that the selection of process parameters allows for obtaining ash with controlled and desired composition of macro and micronutrients, moreover, it is safe in terms of sanitary.
\end{abstract}

Keywords Ash · Feather - Macronutrients $\cdot$ Meat and bone meal $\cdot$ Micronutrients $\cdot$ Poultry litter

Editorial responsibility: Ta Yeong Wu.

P. Staroń

pstaron@chemia.pk.edu.pl

1 Department of Engineering and Chemical Technology, Cracow University of Technology, 24 Warszawska St., 31-155 Kraków, Poland

\section{Introduction}

Increases in agricultural production have resulted in an increased demand for fertilizers, including phosphate fertilizers. It is forecasted that by the year 2016/17, the world demands for fertilizer will reach $192.8 \mathrm{Mt}$ (Lim et al. 2015). The main raw materials used in the production of phosphate fertilizers are mineral apatites. Total apatite reserves are difficult to estimate because of challenging political situations and a lack of disclosure from major manufacturers; however, it is expected that existing apatite mineral reserves will last for another 200 years. China, the United States and Morocco are among the largest producers of mineral phosphorus in the world. Within the European Union, Finland is the only operating source of phosphate. Therefore, the development and implementation of sustainable methods of phosphorus recycling is paramount (Dawson and Hilton 2011).

The meat industry generates significant amounts of waste derived from meat, bone meal, feathers and poultry litter. This waste is rich in phosphorus and other valuable elements such as calcium, potassium, and magnesium, all of which are important components of fertilizer. However, the animal wastes which has been used in agricultural fields as a fertilizer deriving from livestock without prior suitable pre-treatment can cause potentially harmful effects to the environment, e.g. increase of antibiotics level in soil (Ravindran and Mnkeni 2016).

In recent years, poultry meat and pork production in the European Union (EU) has surpassed beef production (Białas et al. 2015). In 2013, production of poultry meat reached 12.6 million tons, increasing by $7 \%$ over 5 years (Europa 2016a, b). Relative to other livestock industries, the poultry industry has undergone the most rapid technological progress, characterized by nutritional and genetic 
advancements. This has allowed the poultry industry to transition from small poultry farms to farms that use intensive production systems. Increased production has resulted in an increase in generated waste, including feather waste, which must be disposed of in accordance with EU regulations. Within a year millions of tons of feather waste are produced (Demir et al. 2015). Due to the lack of easy and economical methods for feather processing into the environmental friendly product, it is stored in the unprocessed form (Tran et al. 2016).

Currently, the majority of the feather wastes are processed by chemical and thermal into feather meal, which is used as animal feed in the poultry industry. However, these processes are very energy consuming (Demir et al. 2015). There has been various works using waste feather as a biosorbents for heavy metals removal from surface water. However, heavy metal bioremediation attempts from industrial wastewater and other chemically contaminated wastes have led to accumulation of polluted feathers (Yusuf et al. 2016). An alternative method of waste feather processing is the extraction of their keratin which can be used in hydrogel forming widely used for wound healing and for the biocompatibility tests in vivo (Wang et al. 2017)

In the poultry sector, chicken manure is a significant source of waste, and is composed of a mixture of manure, litter (including sawdust and straw), feed remains, broken shells, and feathers. These components have high nutritional value, allowing chicken manure to be used as organic fertilizer that provides a good source of nitrogen, phosphorus and potassium (Kelleher et al. 2002; Abelha et al. 2003; Dávalos et al. 2002; Liu et al. 2016). Poultry produces about $60-70 \mathrm{~kg}$ poultry litter in a year per animal (Yurdakul 2016). However, animal droppings cause the most environmental problems, e.g.: greenhouse gases, odors, ammonia, high counts of fecal coliform bacteria and pathogens, the release of animal pathogens and contamination of surface and groundwater (Tufaner and Avsar 2016). One of the proposed methods for the removal of poultry litter is processing it into biogas. The cost of this process is not very high but the biogas efficiency is low (Miah et al. 2016). Recently, the European Commission (EC) has decided to allow the use of poultry litter as a fuel for on-farm combustion under existing animal byproduct regulations (Commission Regulations 2014). This capability provides a number of benefits for farmers, including heat required in the winter for henhouses and obtaining natural fertilizer without having to incur additional costs of disposal and transport (Taupe et al. 2016).

The use of meat and bone meal as feed additives have been prohibited since July 1994, when several cases of bovine spongiform encephalopathy (BSE) were detected in cattle that had been fed ruminant remains. Infected animals are considered high-risk material, and have to be disposed of by incineration. Waste from infected animals is subjected to sterilization at a pressure of at least 3 bar at $133{ }^{\circ} \mathrm{C}$ for $20 \mathrm{~min}$. The meat and bone meal (MBM) that is formed during this process is granular and sticky, contains bone fragments, and consists of large amounts of volatile matter and ash. Importantly, MBM is a rich source of calcium and phosphorus (Fryda et al. 2007; Wu et al. 2009; Conesa et al. 2005). The total production of meat and bone meal in the European Union is approximately 3.5 million tonnes per year (Coutand et al. 2008). Currently, the most widely used method of disposing MBM is its combustion in cement kilns. In addition, there are many works depicting the method of disposal of MBM including MBM as extra fuel for coal enrichment. Also there are works in which pyrolysis and gasification methods had been used alternatively to combustion methods (Cascarosa et al. 2013; Barbosa et al. 2012). Moreover changes in EU rules allowed the use of MBM for partial (up to 50\%) replacement of fish meal in the diet of young seabream juveniles (Moutinho et al. 2017).

Waste from the meat industry is also classified as hazardous and must be disposed of in an appropriate manner. Health regulations require that waste be disposed of through thermal processing. The ash product that is obtained from this process is rich in macronutrients such as phosphorus, calcium, potassium, sodium and magnesium, as well as micronutrients such as iron, copper, manganese and zinc. These components have high fertilizing value.

The aim of this study was to carry out the thermal processing of waste from the meat industry in a high scale rotary kiln. This type of furnace can be used to gain information about thermal waste processing in pilot scale that can be extrapolated to the large-scale thermal treatment of waste. Rotary kilns are the most commonly used furnaces in factories that thermally treat waste from the meat industry. They are widely used in thermal treatment of hazardous waste and they are recommended by IPPC (Reference Document on the Best Available, Techniques for Waste Incineration). The ash that is formed from the combined thermal treatment of waste feathers, poultry litter, and MBM has a more favorable elemental composition than the ash formed by burning just one type of waste. This study also aimed to determine ash physico-chemical properties, and the effect that different process parameters have on ash macro- and micronutrient content. The benefits of the thermal treatment of meat industry waste are twofold: it generates ash that is safe and sanitary, and it provides a product whose composition is ideal for use in fertilizer applications. In addition, this type of processing overcomes some of the challenges that are associated with the large amount of waste that is generated by the poultry 
industry, an outcome that is in line with the objectives of sustainable development and advancement of cleaner technologies. The novelty of this work is the ability of obtaining of specific ash composition which is possible thanks to use of statistical methods of data exploring. Experiments were conducted in the years 2013-2015 in the High scale Research Laboratory of Cracow University of Technology, Poland.

\section{Materials and methods}

\section{Materials}

In this study, the test material consisted of waste feathers $(\mathrm{F})$, poultry litter $(\mathrm{PL})$, and meat and bone meal (MBM). Hen feathers were obtained from a poultry slaughterhouse. Feathers were taken immediately after slaughter and were not subjected to any mechanical treatments. MBM was obtained by thermal treatment, and was partially defatted. Poultry litter came from a production plant carrying out litter breeding, and was obtained from the warehouse in which it was stored. During storage, partial evaporation of moisture from the poultry litter had taken place. Table 1 shows the characteristics of the research material. Due to about $90 \%$ part of the keratin in the feathers, the high content of carbon $(50 \%)$ and about $14 \%$ of nitrogen is characteristic. A significant amount of organic compounds affect the calorimetry test results. Feathers heat of combustion (air-dry state) is high, more than $23 \mathrm{MJ} / \mathrm{kg}$. Organic origin of MBM and fat content causes the meat and bone meal is characterized by high organic carbon content (over 40\%) and nitrogen (over 8\%), what results in its high heat of combustion (approx. $11 \mathrm{MJ} / \mathrm{kg}$ ). The mineral part present in poultry litter, originating from the ground straw affect the lower carbon, hydrogen and nitrogen in comparison to the contents of these elements in feathers and meat and bone meal and the calorific value $(\sim 12 \mathrm{MJ} / \mathrm{kg})$.

Table 1 Content of C, H, N elements, moisture, and heat of combustion of the test material

\begin{tabular}{lccc}
\hline & Feathers & $\begin{array}{l}\text { Meat and } \\
\text { bone meal }\end{array}$ & $\begin{array}{l}\text { Poultry } \\
\text { litter }\end{array}$ \\
\hline $\begin{array}{l}\text { Elemental analysis (\%) } \\
\mathrm{C}\end{array}$ & 48.21 & 41.30 & 31.94 \\
$\mathrm{H}$ & 7.41 & 6.24 & 4.60 \\
$\mathrm{~N}$ & 13.73 & 8.30 & 2.99 \\
$\begin{array}{l}\text { Moisture content (\%) } \\
\text { Heat of combustion }\end{array}$ & 54.6 & 4.2 & 13.4 \\
$(\mathrm{MJ} / \mathrm{kg})$ & 23.4 & 17.2 & 11.8 \\
\hline
\end{tabular}

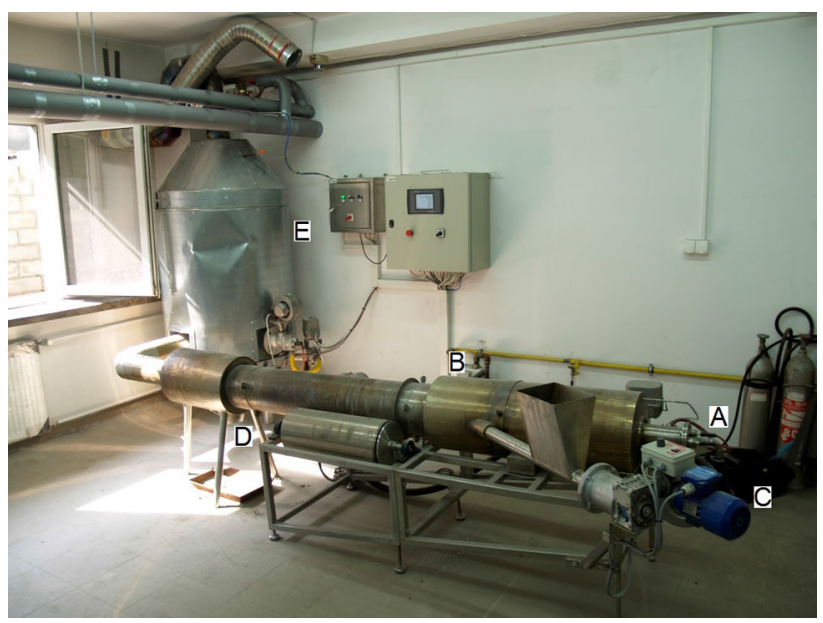

Fig. 1 High scale rotary kiln

\section{Methods}

Test materials were incinerated in a high scale rotary kiln (Fig. 1) that was $120 \mathrm{~cm}$ in length and $15 \mathrm{~cm}$ in diameter. The inner lining of the furnace was made of ceramic aluminosilicate, with a high content of $\mathrm{Al}_{2} \mathrm{O}_{3}$. The gas burner (A) was located in the front chamber of the oven. With the use of thermocouple (B) the temperature at the material entry into the kiln was measured. A screw-conveyor feeder (C) was used to feed materials to the furnace at a regular dosage. Ash was received at the end of the kiln (D). At the end of the installation the exhaust gases afterburner was installed (E), which was supplied with the additional gas burner $\left(900^{\circ} \mathrm{C}\right)$. The presence of the exhaust afterburner was dictated by the requirement of chemical compounds, mainly odorous and compounds which may contain nitrogen and chlorine in the exhaust gases. The turnover of the furnace was approximately $1.3 \mathrm{rev} / \mathrm{min}$, allowing the material to remain in the incineration zone for approximately $20 \mathrm{~min}$. Materials were incinerated at $600,700,800$ and $900{ }^{\circ} \mathrm{C}$. The indicated temperatures were achieved in the initial kiln fragment, in the place of raw material feeding.

\section{Physico-chemical characteristics of mineral residues}

Elemental analyses (analysis of $\mathrm{C}, \mathrm{H}$ and $\mathrm{N}$ content) were performed on a Type 2400 CHN Analyser from Perkin Elmer. Heat of combustion measurements were made using a KL-12Mn Precyzja-Bit calorimeter.

The elemental analysis of ash was carried out with an OPTIMA 7300 DV inductively coupled plasma-optical emission spectrometer (ICP-OES) made by Perkin Elmer. The test material was mineralized by boiling in the following concentrated acids: hydrofluoric acid (HF), nitric acid (V) $\left(\mathrm{HNO}_{3}\right)$, and chloric acid (VII) $\left(\mathrm{HClO}_{4}\right)$. 
Approximately $0.2 \mathrm{~g}$ of test material was used for the mineralization process. The first step was carried out in $4 \mathrm{~cm}^{3} \mathrm{HF}$. After the acid evaporated, $8 \mathrm{~cm}^{3}$ of an acid mixture of $\mathrm{HNO}_{3}$ and $\mathrm{HClO}_{4}$ (1:1) was added. After the evaporation of this acid mixture, an additional $8 \mathrm{~cm}^{3}$ of $\mathrm{HNO}_{3}$ and $\mathrm{HClO}_{4}(1: 1)$ mixture was added.

To evaluate whether the ash would be useful for fertilizing purposes, the phosphorus content of the ash (including phosphorus dissolved in citric acid, which provides a measure of phosphorus that is available to plants) was determined. Sodium, potassium and ammonium phosphates are water soluble regardless of the degree of dissociation. Calcium phosphates are soluble in water only at the first degree of dissociation $\left(\mathrm{H}_{2} \mathrm{PO}_{4}{ }^{-}\right)$, at the second degree of dissociation $\left(\mathrm{HPO}_{4}{ }^{2-}\right)$ they are soluble in citric acid, and at the third degree of dissociation $\left(\mathrm{PO}_{4}{ }^{3-}\right)$ only in strong mineral acids. As a measure of phosphate bioavailability for the animal organisms solubility in $\mathrm{HCl}$ was used, $\mathrm{HCl}$ concentration corresponds to the concentration of hydrochloric acid in the gastric juices. Total phosphorus content $\left(\mathrm{P}_{\mathrm{t}}\right)$, and phosphorus soluble in hydrochloric acid $\left(\mathrm{P}_{\mathrm{h}}\right)$ and citric acid $\left(\mathrm{P}_{\mathrm{c}}\right)$, was determined by spectrophotometry using a Nanocolor UV/VIS Macherey-Nagel Company spectrophotometer. This method is based on the formation of a yellow-colored complex of phosphorusvanadium-molybdenum and measurement of its photometric absorbance at $430 \mathrm{~nm}$. For the determination of total phosphorus content, samples were mineralized as follows: samples were boiled in a mixture of nitric acid and hydrochloric acid (3:1) for $15 \mathrm{~min}$, then water was added and samples were maintained at a boiling temperature for $15 \mathrm{~min}$. The extraction of phosphorus soluble in hydrochloric acid was carried out in $1 \mathrm{~mol} / \mathrm{dm}^{3} \mathrm{HCl}$, and the extraction of phosphorus soluble in citric acid was carried out in $2 \%$ citric acid. Phosphorus extraction in citric acid and hydrochloric acid was carried out for $30 \mathrm{~min}$ (PNR-64803, 1997).

The phase composition of ash was determined by X-ray diffraction using an X-Pert Philips diffractometer equipped with a graphite monochromator (PW 1752-1700). A specific surface area test was carried out using a Macrometrics camera capable of measuring micropores, and an ASAP 2010 deaerator station. Before measurement, samples were dried in a helium atmosphere at $110{ }^{\circ} \mathrm{C}$ for $8 \mathrm{~h}$, then under vacuum at $100{ }^{\circ} \mathrm{C}$ and 0.001 Tor for $8 \mathrm{~h}$. Surface analysis was performed with an LEO 1430 VP scanning electron microscope (LEO 1430 VP made by Electron Microscopy Ltd).

In order to determine which ash composition contained the highest content of macro- and micronutrients, we conducted statistical analyses on the data that we collected and constructed an empirical model for the thermal treatment of waste. Empirical models provide numerical descriptions of the relationships between research parameters. Fitting a regression equation for input factors to the measured value of the output factors (profile approximation) made it possible to determine the size of the input (x) that provided the most favorable (useful) predicted output value (s). Approximated output values for each combination of input values were used to construct a utility scale. The relationship between the approximated output values and the usability response is a function of utility. Utility values may vary from 0.0 (undesirable) to 1.0 (very desirable). The use of profile approximation and utility functions enabled us to identify which ash composition contained the highest content of macro- and micronutrients.

The resulting profile approximation (fitting the equation of regression of independent parameters for the dependent parameters) allows the value of input factors that ensure the most desirable (useful) estimated values of output factors to be determined. Due to the obtained approximation profile, it is possible to optimize the product usability. Utility function (desirability) is the relationship between the approximated (predicted) responses of the output parameters values and their usability.

\section{Results and discussion}

Table 2 summarizes the total phosphorus content, phosphorus soluble in citric acid and hydrochloric acid, and the elemental composition of the ash obtained after binary incineration [co-incineration of feathers and meat and bone meal $(\mathrm{F}+\mathrm{MBM})$, or co-incineration of feathers and poultry litter $(\mathrm{F}+\mathrm{PL})]$ in a high scale rotary kiln.

The phosphorous content of ash obtained in a rotary kiln after incineration of a mixture of feathers and meat and bone meal, or a mixture of feathers and poultry litter, was 8-17 and 4-5\%, respectively. Phosphorus present in the ash was highly soluble in hydrochloric acid, and less soluble in citric acid. The phosphorus content depended on the composition of the waste input, and on incineration temperature. MBM is a rich source of phosphorus, and therefore enhances the phosphorous content of ash. Moreover, an increase in the mass fraction of meat and bone meal and poultry litter in input waste enhances the calcium content of ash. The high phosphorus and calcium content of MBMderived ash is consistent with the research of Fryda et al. who studied the burning of MBM with two types of coal in a laboratory-scale fluidized bed combustor (Fryda et al. 2007). Poultry litter enriches the potassium content of ash, as shown by Guerra-Rodriguez et al. who characterized the nutrient content of compost produced by the co-composting of chestnut burr, leaf litter and solid poultry manure (Guerra-Rodriguez et al. 2001). The use of increased temperature during processing promotes the afterburning of 


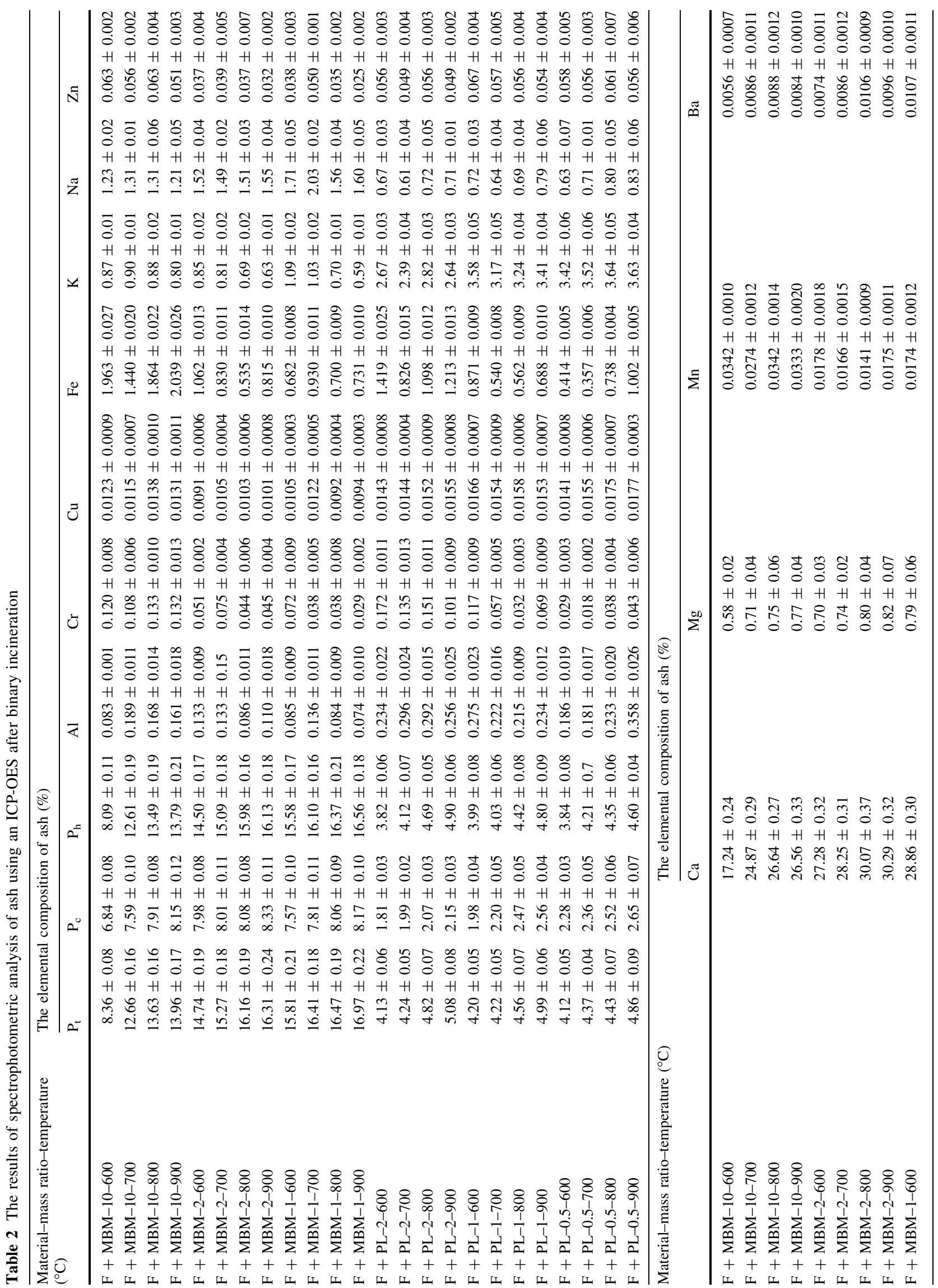




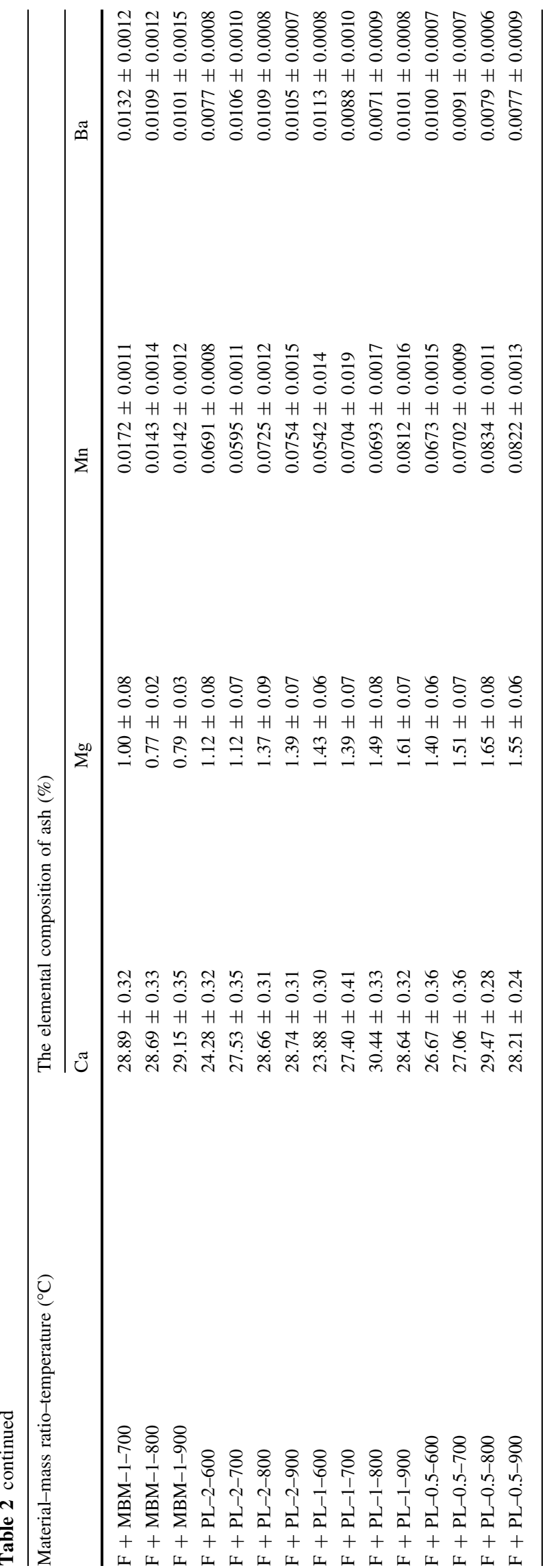

waste, resulting in an increase in the elemental content of the processed material.

\section{Physico-chemical characteristics of ash}

Table 3 shows the results of analysis of the phase composition of ash produced after binary incineration in a rotary kiln.

$\mathrm{X}$-ray analysis of the ash obtained from the binary incineration of meat and bone meal identified the presence of hydroxyapatite and calcium carbonate. This can be attributed to the phase composition of the tested system, which is mostly residue resulting from the incineration of MBM (Staron et al. 2016). The ash obtained from the binary incineration of poultry litter contained calcium carbonate, potassium and magnesium phosphates. Diffractograms were constructed for the ashes obtained by burning the mixture at $900{ }^{\circ} \mathrm{C}$. Reflections derived from hydroxyapatite and calcium carbonate, the main components of MBM, were evident in the diffraction pattern of ash formed after thermal conversion of a mixture of feathers and meat and bone meal at mass ratios of $\mathrm{F}: \mathrm{MBM}=10: 1$ and 2:1. Potassium-magnesium phosphate was also evident due to the presence of feathers in the mixture, which are a rich source of phosphorus, potassium, magnesium and calcium. These findings are consistent with those of Sosnowska et al. (2015), who studied fireside deposition during the industrial gasification of feathers, and with those of Dudyński et al. (2012), who studied the process of obtaining syngas from feathers. In all cases, analysis of the phase composition of ash after incineration of a mixture of feathers and poultry litter revealed the presence of calcium carbonate, phosphate, potassium and magnesium. Calcium oxide, which is formed during the decomposition of calcium carbonate, was also detected. Kaikake et al. also identified the presence of these compounds in studies of the recovery of phosphorus from solutions obtained from chicken manure ash (Kaikake et al. 2008).

Structural analysis of the ash surface showed that the ash obtained after incineration of an F + MBM mixture at a temperature of $600{ }^{\circ} \mathrm{C}$ is characterized by crystallites with an average size of approximately $200 \mathrm{~nm}$ and a narrow range of variation. In addition to spherical crystallites, stick-shaped crystallites with an average width of $100 \mathrm{~nm}$ and a length of $400 \mathrm{~nm}$ were also evident (Fig. 2a). When incinerated at $900{ }^{\circ} \mathrm{C}$, ash derived from the $\mathrm{F}+\mathrm{MBM}$ mixture was comprised of polygon-shaped particles that had more stringent edges than ash incinerated at $600{ }^{\circ} \mathrm{C}$. Sticks of varying length (from 80 to $500 \mathrm{~nm}$ ), with an average width of $80-130 \mathrm{~nm}$, were most evident. Plate inclusions with an average width of 200-600 nm and an average length of $200-800 \mathrm{~nm}$ were also visible. Local 
Table 3 The phase composition of ash after binary incineration

\begin{tabular}{|c|c|c|c|c|}
\hline \multirow[t]{2}{*}{ Material-mass ratio-temperature $\left({ }^{\circ} \mathrm{C}\right)$} & \multicolumn{4}{|c|}{ Phase composition of ash } \\
\hline & $\mathrm{Ca}_{10}\left(\mathrm{PO}_{4}\right)_{6}(\mathrm{OH})_{2}$ & $\mathrm{CaCO}_{3}$ & $\mathrm{~K}_{2} \mathrm{Mg}\left(\mathrm{PO}_{3}\right)_{4}$ & $\mathrm{CaO}$ \\
\hline$F+M B M-10-600$ & $\mathrm{X}$ & $\mathrm{X}$ & & \\
\hline $\mathrm{F}+\mathrm{MBM}-10-700$ & $\mathrm{X}$ & $\mathrm{X}$ & & \\
\hline $\mathrm{F}+\mathrm{MBM}-10-800$ & $\mathrm{X}$ & $\mathrm{X}$ & & \\
\hline $\mathrm{F}+\mathrm{MBM}-10-900$ & $\mathrm{X}$ & $\mathrm{X}$ & & \\
\hline$F+M B M-2-600$ & $\mathrm{X}$ & $\mathrm{X}$ & & \\
\hline $\mathrm{F}+\mathrm{MBM}-2-700$ & $\mathrm{X}$ & $\mathrm{X}$ & & \\
\hline$F+M B M-2-800$ & $X$ & & & \\
\hline F + MBM-2-900 & $\mathrm{X}$ & $\mathrm{X}$ & & \\
\hline$F+M B M-1-600$ & $\mathrm{X}$ & & $X$ & \\
\hline$F+M B M-1-700$ & $X$ & & $X$ & \\
\hline$F+M B M-1-800$ & $\mathrm{X}$ & $\mathrm{X}$ & & \\
\hline $\mathrm{F}+\mathrm{MBM}-1-900$ & $\mathrm{X}$ & $\mathrm{X}$ & $\mathrm{X}$ & \\
\hline $\mathrm{F}+\mathrm{PL}-2-600$ & & $\mathrm{X}$ & $\mathrm{X}$ & \\
\hline $\mathrm{F}+\mathrm{PL}-2-700$ & & $\mathrm{X}$ & $\mathrm{X}$ & $\mathrm{X}$ \\
\hline $\mathrm{F}+\mathrm{PL}-2-800$ & & $\mathrm{X}$ & $\mathrm{X}$ & $\mathrm{X}$ \\
\hline $\mathrm{F}+\mathrm{PL}-2-900$ & & $\mathrm{X}$ & $\mathrm{X}$ & $\mathrm{X}$ \\
\hline$F+$ PL-1-600 & & $\mathrm{X}$ & $\mathrm{X}$ & \\
\hline$F+$ PL-1-700 & & $\mathrm{X}$ & $\mathrm{X}$ & \\
\hline$F+$ PL-1-800 & & $\mathrm{X}$ & $\mathrm{X}$ & $\mathrm{X}$ \\
\hline F + PL-1-900 & & $\mathrm{X}$ & $\mathrm{X}$ & $X$ \\
\hline$F+$ PL-0.5-600 & & $\mathrm{X}$ & $\mathrm{X}$ & $\mathrm{X}$ \\
\hline$F+$ PL-0.5-700 & & $\mathrm{X}$ & $\mathrm{X}$ & \\
\hline$F+$ PL-0.5-800 & & $\mathrm{X}$ & $X$ & $X$ \\
\hline$F+$ PL-0.5-900 & & $\mathrm{X}$ & $X$ & $X$ \\
\hline
\end{tabular}

$\mathrm{X}$ - presence of indicated component in the obtained ash crystallites formed agglomerates (Fig. 2b). The ash from incineration of the F + MBM mixture in our study was similar to the ash obtained from incineration of the MBM mixture studied by Deydier et al. (2005), except that these researchers observed crystallites of different size and shape.

The ash obtained from incineration of a mixture of $\mathrm{F}+\mathrm{PL}$ at a temperature of $600{ }^{\circ} \mathrm{C}$ had a compact structure, was highly folded, and had a poorly developed dominant shape (larger agglomerates were $500 \mathrm{~nm}$ in size on average). Spherical particle inclusions were evident that had an average diameter of $120 \mathrm{~nm}$ (Fig. 3a). Incineration of the $\mathrm{F}+\mathrm{PL}$ mixture at $900{ }^{\circ} \mathrm{C}$ produced ash that was compact in structure. This ash consisted of spherical particles with an average diameter of $70 \mathrm{~nm}$ that were homogenously distributed over the ash surface (Fig. 3b). Incineration at $600{ }^{\circ} \mathrm{C}$ is not sufficient to allow the complete coalescence of the ash to spherical particles. Following incineration at high temperatures, ash particles become more fragile (i.e. their crystalline matter content increases). Therefore, higher combustion temperatures increase particle cracking, resulting in particles that are smaller in size (Acharya et al. 2014).
The relative amounts of meat and bone meal and poultry litter in waste before incineration, and the incineration temperature, influence the characteristics of the resulting ash surface. Incineration of waste at $600{ }^{\circ} \mathrm{C}$ with the highest ratio of MBM:feathers produced ash with the highest specific surface area development, as confirmed by BET analysis (Table 4). The presence of organic matter in the meat and bone meal makes the incineration process easier. At high temperatures, the partial sintering of hydroxyapatite in the ash occurs, which reduces ash surface area. According to Wang et al. at temperatures above $780{ }^{\circ} \mathrm{C}$, changes in the specific surface area and density of hydroxyapatite result from shrinkage that occurs during sintering (Wang et al. 2008).

\section{The influence of process parameters on the elemental composition of ash after incineration of a mixture of feathers and meat and bone meal}

Feathers, poultry litter and meat and bone meal is characterized by the various amounts of macro and micronutrients. The aim to obtain ash characterized by the preferred 

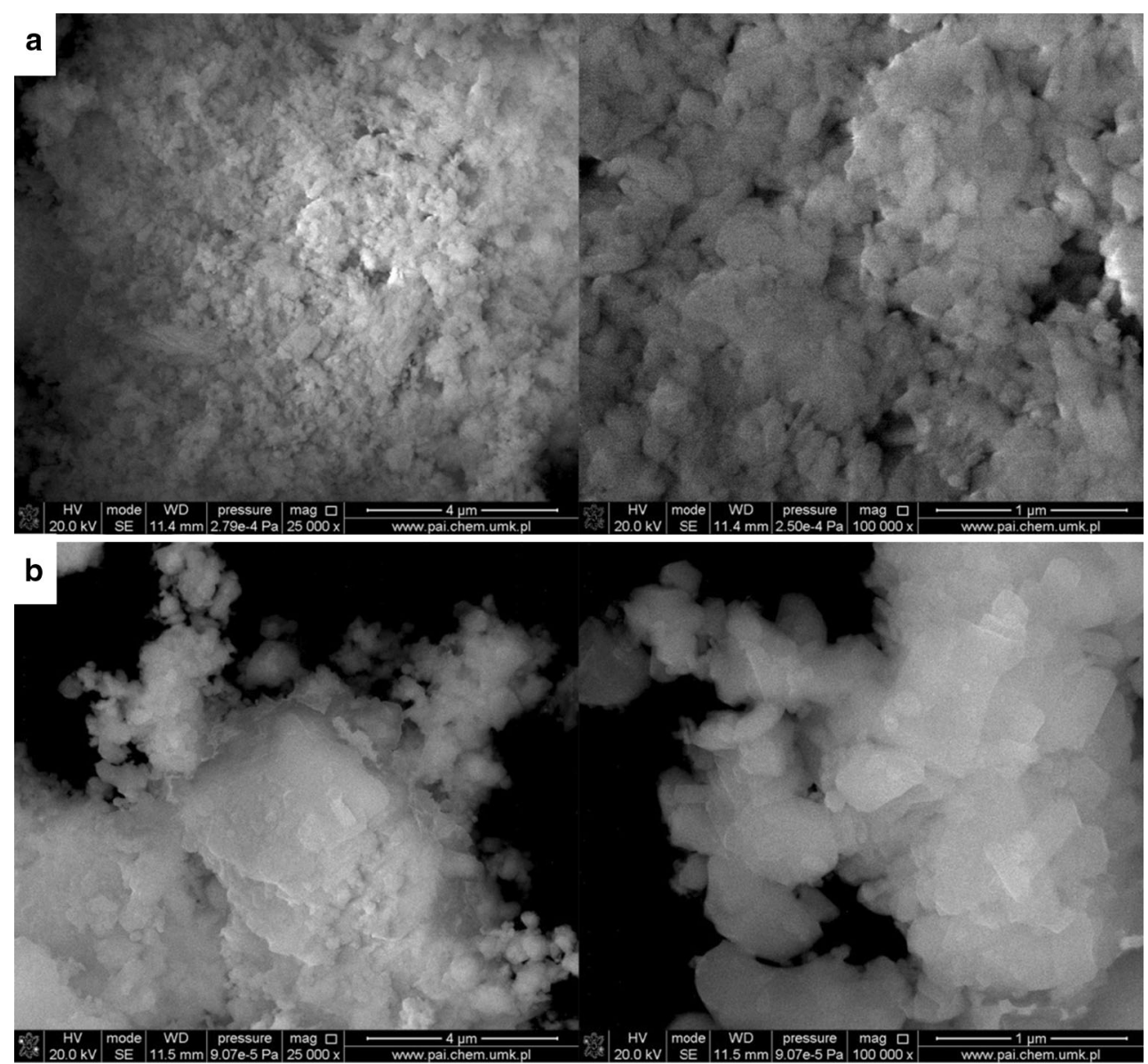

Fig. 2 SEM microphotographs of mixtures of: a F + MBM (1:1) after incineration at $600{ }^{\circ} \mathrm{C}$, and $\mathbf{b} \mathrm{F}+\mathrm{MBM}(1: 1)$ after incineration at $900{ }^{\circ} \mathrm{C}$

elemental composition, the effect of process parameters: temperature of the combustion process and the mass ratio of the MBM feathers and poultry litter were examined.

\section{The influence of process parameters on the elemental composition of ash after incineration of a mixture of feathers and meat and bone meal}

Macronutrients When the residence time of the material in the kiln is constant, an increase in incineration temperature appears to enhance the burnout of the material and the crystallinity of the ash. Incineration temperature, and the interaction between temperature and the mass ratio of the materials in the mixture, affected the content of all types of phosphorus. These factors also influenced the sodium and calcium content of the ash. An increase in the relative mass of MBM in the mixture is known to increase the content of phosphorus, sodium, and calcium in the ash (Fryda et al. 2007; Skodras et al. 2007; Ghaly et al. 2012). In contrast, potassium content depends on incineration temperature. Operation at high temperatures results in potassium loss through volatilization (Misra et al. 1993).
Magnesium content is not affected by any statistically significant parameter.

Our nutrient profile analysis indicates that the macronutrient content of ash can be maximized by incineration at $900{ }^{\circ} \mathrm{C}$ of a mixture of $\mathrm{F}+\mathrm{MBM}$ at a mass ratio of 1:1 (Fig. 4). The residence time of the material in the kiln (20-25 min) was not sufficient for the complete conversion of feathers to ash, in contrast to meat and bone meal, which was completely converted. To achieve the maximum yield of phosphorus, sodium, calcium and magnesium, incineration in a rotary kiln should be carried out using the lowest possible mass ratio of feathers to meat and bone meal. Ash generated using processing parameters that maximize macronutrient yield will have the following composition: $\mathrm{P}_{\mathrm{t}}-16.83 \%, \mathrm{P}_{\mathrm{c}}-8.27 \%, \mathrm{P}_{\mathrm{h}}-16.48 \%, \mathrm{~K}-$ $0.63 \%, \mathrm{Na}-1.63 \%, \mathrm{Ca}-32.34 \%$, and $\mathrm{Mg}-0.85 \%$.

Micronutrients The content of iron, copper and manganese in the ash obtained from mixtures of $\mathrm{F}+\mathrm{MBM}$ was affected by the mass ratio of feathers to meat and bone meal. The content of zinc was dependent on the mass ratio of the raw materials, and on incineration temperature. Micronutrient 

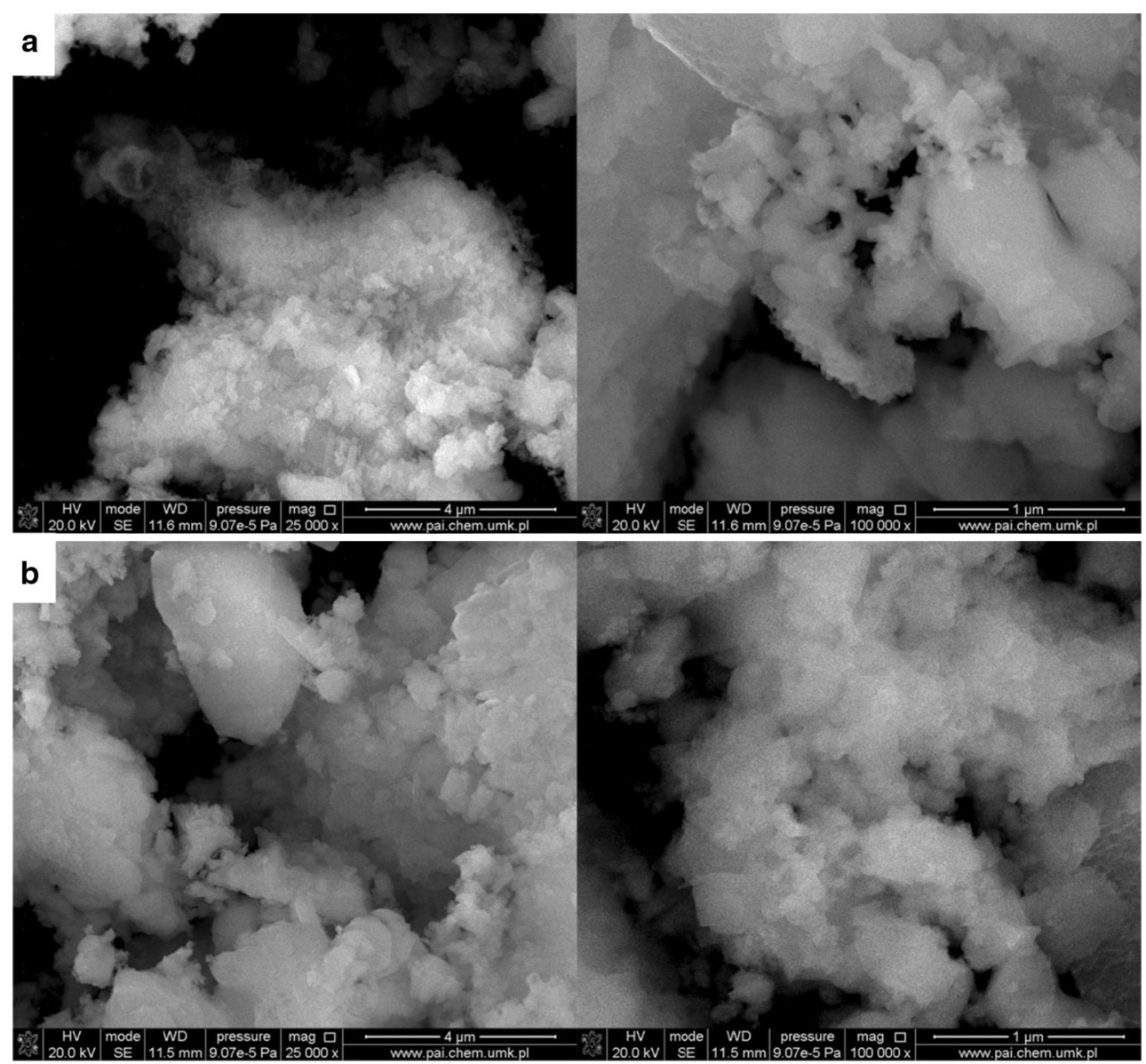

Fig. 3 SEM microphotographs of mixtures of: a F + PL (1:2) after incineration at $600{ }^{\circ} \mathrm{C}$, and $\mathbf{b} \mathrm{F}+\mathrm{PL}(1: 2)$ after incineration at $900{ }^{\circ} \mathrm{C}$

Table 4 BET analysis of ashes

\begin{tabular}{lll}
\hline $\begin{array}{l}\text { Material-mass } \\
\text { ratio-temperature }\left({ }^{\circ} \mathrm{C}\right)\end{array}$ & $\begin{array}{l}\text { Surface area } \\
\left(\mathrm{m}^{2} / \mathrm{g}\right)\end{array}$ & $\begin{array}{l}\text { Total porous } \\
\text { surface }\left(\mathrm{m}^{2} / \mathrm{g}\right)\end{array}$ \\
\hline $\mathrm{F}+$ MBM-1-600 & 7.1764 & 4.560 \\
$\mathrm{~F}+$ MBM-1-900 & 2.9982 & 1.666 \\
$\mathrm{~F}+$ PL-0.5-600 & 2.4549 & 1.474 \\
$\mathrm{~F}+$ PL-0.5-900 & 4.1169 & 2.518 \\
\hline
\end{tabular}

content in the ash was affected by the quantity of feathers in the input mixture. Feathers, which are a rich source of iron, zinc and manganese, enrich ash with these elements. Previous work has shown that a high mass ratio of feathers to MBM should be used to ensure that the content of these minerals in the ash is high (Staron et al. 2016). The content of various micronutrients in feathers depends on a bird's diet during growth and development (e.g. metals are incorporated into the structure of keratin when blades are connected to blood vessels) (Abduljaleel et al. 2012).

Our nutrient profile analysis indicates that the micronutrient content of ash can be maximized by incineration at $600{ }^{\circ} \mathrm{C}$ of a mixture of $\mathrm{F}+\mathrm{MBM}$ at a mass ratio of 10:1. These conditions produce ash with the following composition: $\mathrm{Fe}-1.88 \%$, $\mathrm{Cu}-0.01 \%, \mathrm{Mn}-0.04 \%$, and $\mathrm{Zn}-0.06 \%$. In contrast, ash that is generated using process parameters that maximize macronutrient content will have the following composition: $\mathrm{Fe}-0.70 \%, \mathrm{Cu}-0.01 \%, \mathrm{Mn}-0.01 \%$, and $\mathrm{Zn}-0.03 \%$.

By changing process parameters, ash composition can be modified in a predictable way. This permits the generation of different types of ash with varying nutrient content that are suitable for different applications.

The influence of the process parameters on the elementary content of ash obtained after incineration of a mixture of feathers and poultry litter

Macronutrients The content of total phosphorus, sodium, and calcium in ash is affected by incineration temperature. Both the content of phosphorus soluble in citric acid and hydrochloric acid, and magnesium content, are affected by the weight ratio of raw materials and incineration temperature. The mass ratio of raw materials is the statistically significant parameter that determines potassium content in ash. 


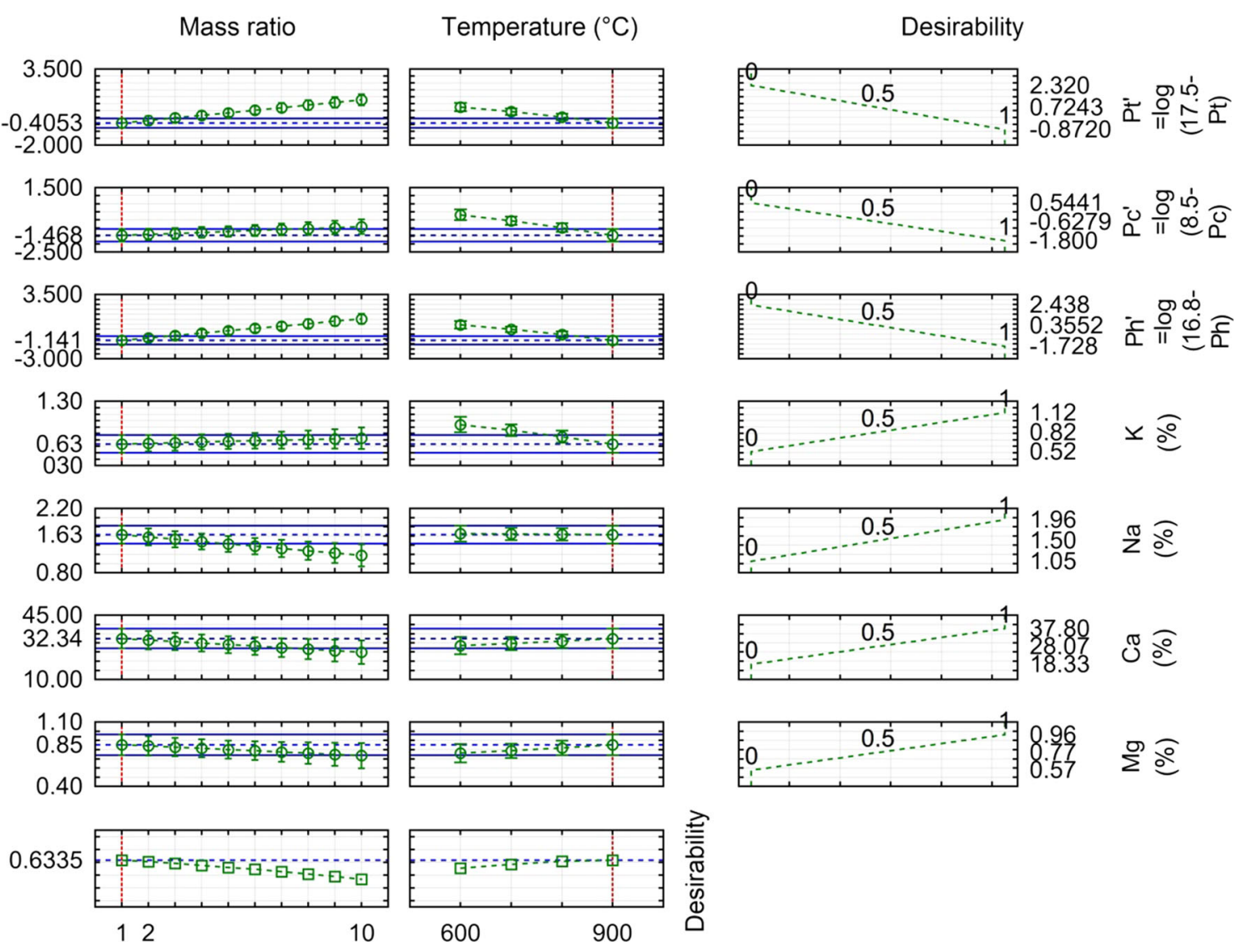

Fig. 4 Approximated macronutrient content profiles, and the utility function, of the mixture $\mathrm{F}+\mathrm{MBM}$

The macronutrient content of ash is affected by the degree of incineration and the mass fraction of the input components. Because materials reside in the furnace for a constant amount of time, the level of material afterburning depends on the process temperature; as process temperature increases, the level of afterburning increases. Ash content varies depending on the mass fraction of the input components. Increased amounts of feathers produce ash that has a higher content of potassium, whereas increased amounts of poultry litter produce ash that has a higher calcium content (Staroń et al. 2016).

To maximize the macronutrient content of ash, incineration of a mixture of feathers and poultry litter should be carried out at a temperature of $900{ }^{\circ} \mathrm{C}$ (Fig. 5). Ideally, mixtures having a mass ratio of $\mathrm{F}: \mathrm{PL}=1: 2$ should be used for incineration. The ash that is obtained under these conditions will have the following composition: $\mathrm{P}_{\mathrm{t}}$ $4.88 \%, \mathrm{P}_{\mathrm{c}}-2.64 \%, \mathrm{P}_{\mathrm{h}}-4.72 \%, \mathrm{~K}-3.58 \%, \mathrm{Na}-0.79 \%$, $\mathrm{Ca}-29.72 \%$, and $\mathrm{Mg}-1.65 \%$.

Micronutrients The content of iron, copper and zinc in ash depends on the mass ratio of the input raw materials. $\mathrm{Mn}$ content depends on the incineration temperature. Higher process temperatures increase the content of trace elements, except for zinc, which is discharged with exhaust gases (Boman et al. 2004; Struis et al. 2004). Input materials containing a higher mass ratio of poultry litter (due to the very short residence time of the material in the kiln, and the resulting lack of feather afterburning) produce ash with a higher micronutrient content (Staroń et al. 2016).

Our nutrient profile analysis indicates that the micronutrient content of ash can be maximized by incineration at $900{ }^{\circ} \mathrm{C}$ of a mixture of $\mathrm{F}+\mathrm{PL}$ at a mass ratio of 1:2. These conditions produce ash with the following composition: $\mathrm{Fe}-0.67 \%, \mathrm{Cu}-0.02 \%, \mathrm{Mn}-0.08 \%$, and $\mathrm{Zn}-0.06 \%$.

\section{Conclusion}

Waste from the meat industry presents a serious danger to the environment. The storage of waste is associated with the entry of pathogenic microorganisms into the soil and groundwater, as well as the evolution of odors and greenhouse gases that contribute to the greenhouse effect. The benefits of the thermal treatment of meat industry waste are two-fold: it can neutralize hazardous waste materials, and it provides a product that can be used as fertilizer. 


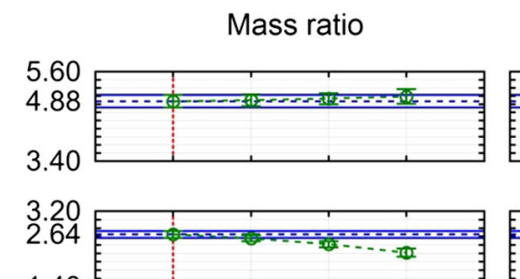

Temperature $\left({ }^{\circ} \mathrm{C}\right)$
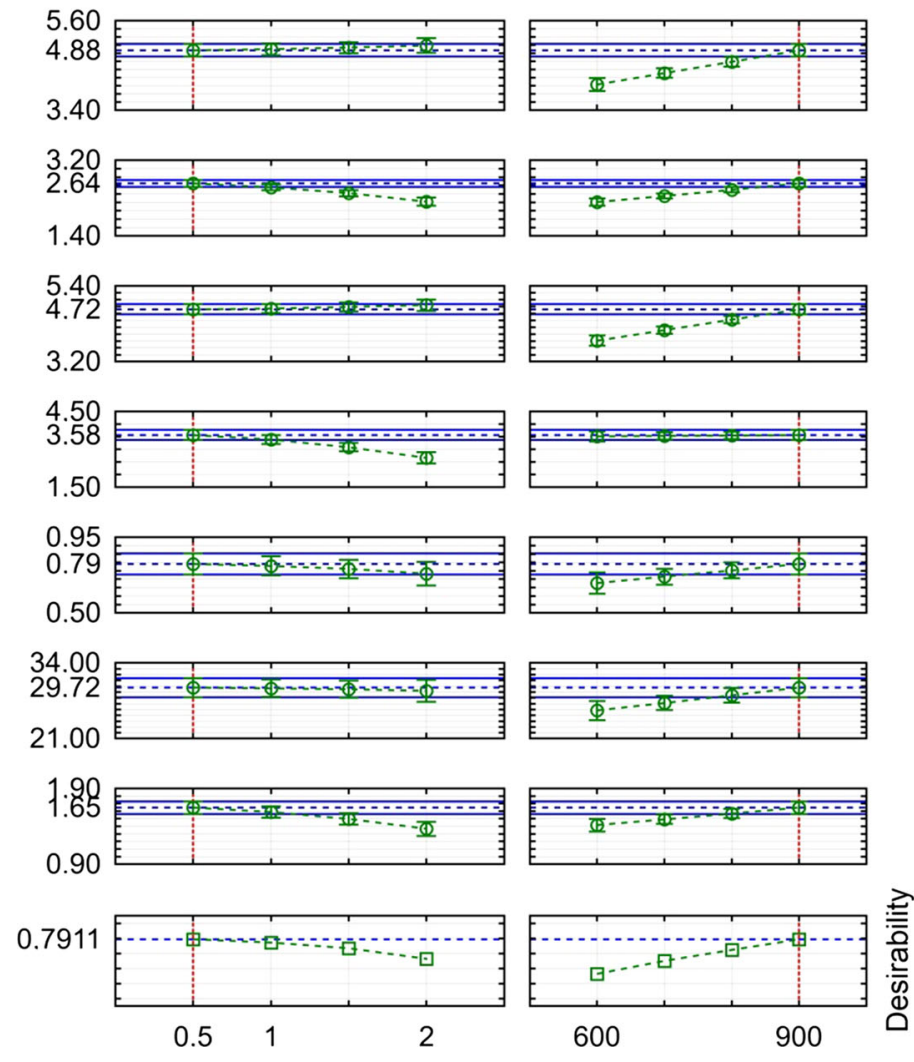

Desirability
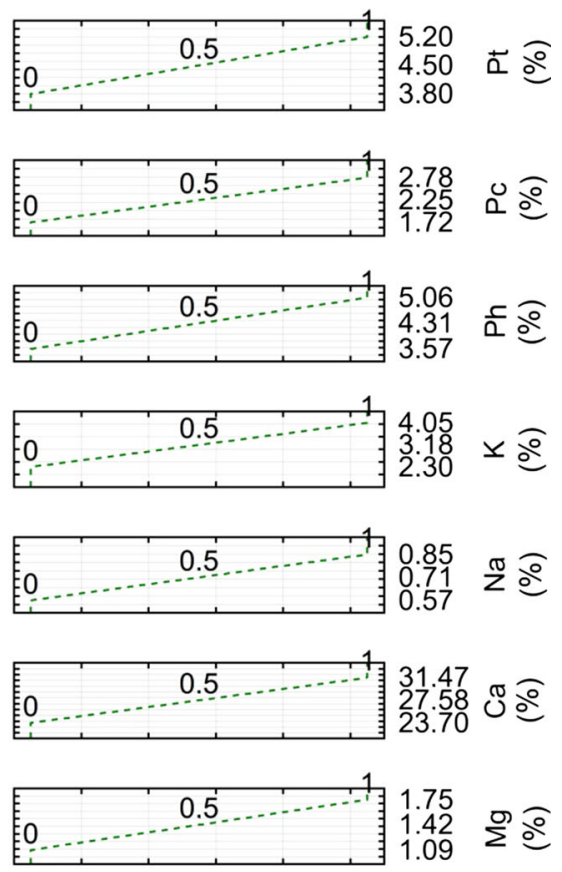

Fig. 5 Approximation profile of the macronutrients and the utility function of the F + PL mixture

Ash obtained after the incineration of feathers, meat and bone meal, and poultry litter contain high quantities of macro- and micronutrients. In order to obtain ash with the highest content of phosphorus, calcium and sodium, a mixture of feathers and MBM with a high mass ratio of MBM should be used for incineration. In contrast, to achieve ash with the highest content of potassium and magnesium, a mixture of feathers and poultry litter should be used for incineration, and should include a high content of feathers. Ash with the optimal composition of micronutrients can be generated from a mixture of feathers and poultry litter with a mass ratio 1:2. For all mixtures, an increase in incineration temperature increases the content of important elements, except for potassium and zinc, which may be lost with exhaust gases.

The disposal of waste from the meat industry by thermal conversion is consistent with the meat industry's model for waste management, and meets the requirements for the sustainable development of clean technology. This process simultaneously disposes of hazardous waste and provides a source of nutrients for the fertilizer industry that can act as a substitute for natural mineral reserves.

Acknowledgements This work is a part of the project Preparation and determination of the applicability of the ashes obtained after incineration of keratin materials for the purposes of fertilizer and feed-research in a laboratory and high scale supported by Ministry of Science and Higher Education under the Project C-1/307/DS-M/ 2013.

Open Access This article is distributed under the terms of the Creative Commons Attribution 4.0 International License (http:// creativecommons.org/licenses/by/4.0/), which permits unrestricted use, distribution, and reproduction in any medium, provided you give appropriate credit to the original author(s) and the source, provide a link to the Creative Commons license, and indicate if changes were made.

\section{References}

Abduljaleel SA, Shuhaimi-othman M, Babji A (2012) Assessment of trace metals contents in chicken (Gallus gallus domesticus) and quail (Coturnix coturnix japonica) tissues from Selangor (Malaysia). J Environ Sci Technol 5:441-451

Abelha P, Gulyurtlu I, Boavida D, Seabra Barros J, Cabrita I, Leathy J, Kellehr B, Leathy M (2003) Combustion of poultry litter in a fluidised bed combustor. Fuel 82:687-692

Acharya B, Dutta A, Mahmud S, Tushar M, Leon M (2014) Ash analysis of poultry litter, willow and oats for combustion in boilers. J Biomass Biofuel 1:16-26

Barbosa R, Lapa N, Lopes H, Mendes B (2012) Chemical and ecotoxicological properties of ashes produced in the co-combustion of coal and meat and bone meal in a fluidized bed reactor. Fuel Process Technol 96:48-55 
Białas W, Stangierski J, Konieczny P (2015) Protein and water recovery from poultry processing wastewater integrating microfiltration, ultrafiltration and vacuum membrane distillation. Int $\mathrm{J}$ Environ Sci Technol 12:1875-1888

Boman C, Nordin A, Boström D, Öhman M (2004) Characterization of inorganic particulate matter from residential combustion of pelletized biomass fuels. Energy Fuels 18:338-348

Cascarosa E, Boldrin A, Astrup T (2013) Pyrolysis and gasification of meat-and-bone-meal: energy balance and GHG accounting. Waste Manag 33:2501-2508

Commission Regulation (EU) (2014) No. 592/2014 of 3 June 2014

Conesa JA, Fullana A, Font R (2005) Dioxin production during the thermal treatment of meat and bone meal residues. Chemosphere 59:85-90

Coutand M, Cyr M, Deydier E, Guilet R, Clastres P (2008) Characteristics of industrial and laboratory meat and bone meal ashes and their potential applications. J Hazard Mater 150:522-532

Dávalos JZ, Roux MV, Jiménez P (2002) Evaluation of poultry litter as a feasible fuel. Thermochim Acta 394:261-266

Dawson CJ, Hilton J (2011) Fertiliser availability in a resourcelimited world: production and recycling of nitrogen and phosphorus. Food Policy 36:S14-S22

Demir T, Hameş EE, Öncel SS, Vardar-Sukan F (2015) An optimization approach to scale up keratinase production by Streptomyces sp. $2 \mathrm{M} 21$ by utilizing chicken feather. Int Biodeterior Biodegrad 103:134-140

Deydier E, Guilet R, Sarda S, Sharrock P (2005) Physical and chemical characterization of crude meat and bone meal combustion residue: "waste or raw material?". J Hazard Mater 121:141-148

Dudyński M, Kwiatkowski K, Bajer K (2012) From feathers to syngas - technologies and devices. Waste Manag 32:685-691

Fryda L, Panopoulos K, Vourliotis P, Kakaras E, Pavlidou E (2007) Meat and bone meal as secondary fuel in fluidized bed combustion. Proc Combust Inst 31:2829-2837

Ghaly AE, Zhang B, Dave D (2012) Degradation of phenolic compounds in creosote treated wood waste by a mixed microbial culture augmented with cellulolytic-thermophilic actinomaycets thermobifida fusca. J Environ Prot 3:83-96

Guerra-Rodriguez E, Diaz-Ravina M, Vazquez M (2001) Cocomposting of chestnut burr and leaf litter with solid poultry manure. Bioresour Technol 78:107-109

http://ec.europa.eu/eurostat/statistics-explained/index.php/ Agricultural_production_-_animals Access 7 June 2016

http://ec.europa.eu/eurostat/statistics-explained/index.php/Meat_ production_statistics Access 07 June 2016

Kaikake K, Sekito T, Dote Y (2008) Phosphate recovery from phosphorus-rich solution obtained from chicken manure incineration ash. Waste Manag 29:1084-1088

Kelleher BP, Leahy JJ, Henihan AM, O'Dwyer TF, Sutton D, Leahy MJ (2002) Advances in poultry litter disposal technology-a review. Bioresour Technol 83:27-36

Lim SL, Wu TY, Lim PN, Shak KPY (2015) The use of vermicompost in organic farming: overview, effects on soil and economics. J Sci Food Agric 95:1143-1156

Liu J, Luo Q, Huang Q (2016) Removal of $17 \beta$-estradiol from poultry litter via solid state cultivation of lignolytic fungi. J Clean Prod 139:1400-1407
Miah MR, Rahman AKL, Akanda MR, Pulak A, Rouf A (2016) Production of biogas from poultry litter mixed with the cosubstrate cow dung. J Taibah Univ Sci 10:497-504

Misra MK, Ragland KW, Baker AJ (1993) Wood ash composition as a function of furnace temperature. Biomass Bioenerg 4:103-116

Moutinho S, Martínez-Llorens S, Tomás-Vidal A, Jover-Cerdá M, Oliva-Teles A, Peres H (2017) Meat and bone meal as partial replacement for fish meal in diets for gilthead seabream (Sparus aurata) juveniles: growth, feed efficiency, amino acid utilization, and economic efficiency. Aquaculture 468:271-277

PN-R-64803 (1997) Feeds-Feed Phosphates

Ravindran B, Mnkeni PNS (2016) Identification and fate of antibiotic residue degradation during composting and vermicomposting of chicken manure. Int J Environ Sci Technol. doi:10.1007/s13762016-1131-z

Reference Document on the Best Available, Techniques for Waste Incineration (2006)

Skodras G, Grammelis P, Basinas P (2007) Pyrolysis and combustion behaviour of coal-MBM blends. Bioresour Technol 98:1-8

Sosnowska M, Dudyński M, Kardas D, Klein M, Kwiatkowski K (2015) Formation of fireside deposits in feather gasification and heat recovery systems - an industrial case study. Fuel Process Technol 139:8-14

Staroń P, Kowalski Z, Staroń A, Seidlerová J, Banach M (2016) Residues from the thermal conversion of waste from the meat industry as a source of valuable macro- and micronutrients. Waste Manag 49:337-345

Struis RPWJ, Ludwig C, Lutz H, Scheidegger AM (2004) Speciation of zinc in municipal solid waste incineration fly ash after heat treatment: an X-ray absorption spectroscopy study. Environ Sci Technol 38:3760-3767

Taupe NC, Lynch D, Wnetrzak R, Kwapinska M, Kwapinski W, Leahy JJ (2016) Updraft gasification of poultry litter at farmscale - a case study. Waste Manag 50:324-333

Tran CD, Prosenc F, Franko M, Benzi G (2016) Synthesis, structure and antimicrobial property of green composites from cellulose, wool, hair and chicken feather. Carbohydr Polym 151:1269-1276

Tufaner F, Avsar Y (2016) Effects of co-substrate on biogas production from cattle manure: a review. Int $\mathrm{J}$ Environ Sci Technol 13:2303-2312

Wang AJ, Lu YP, Zhu RF, Li ST, Xiao GY, Zhao GF, Xu WH (2008) Effect of sintering on porosity, phase, and surface morphology of spray dried hydroxyapatite microspheres. J Biomed Mater Res A 87:557-562

Wang J, Hao S, Luo T, Cheng Z, Li W, Gao F, Guo T, Gong Y, Wang B (2017) Feather keratin hydrogel for wound repair: preparation, healing effect and biocompatibility evaluation. Coll Surf B 149:341-350

Wu G, Healy MG, Zhan X (2009) Effect of the solid content on anaerobic digestion of meat and bone meal. Bioresour Technol 100:4326-4331

Yurdakul S (2016) Determination of co-combustion properties and thermal kinetics of poultry litter/coal blends using thermogravimetry. Renew Energ 89:215-223

Yusuf I, Ahmad SA, Phang LY, Syed MA, Shamaan NA, Khalil KA, Dahalan FA, Shukor MY (2016) Keratinase production and biodegradation of polluted secondary chicken feather wastes by a newly isolated multi heavy metal tolerant bacterium-Alcaligenes sp. AQ05-001. J Environ Manag 183:182-195 